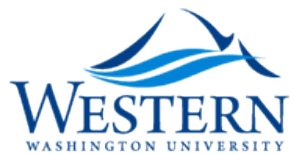

Western Washington University

Western CEDAR

2013

\title{
Avatares de la Suciedad Colonial. La Ciudad de México en los Siglos XVII y XVIII
}

Hugo Garcia

Western Washington University, Hugo.Garcia@wwu.edu

Follow this and additional works at: https://cedar.wwu.edu/mcl_facpubs

Part of the Latin American Languages and Societies Commons, and the Latin American Literature Commons

\section{Recommended Citation}

Garcia, Hugo, "Avatares de la Suciedad Colonial. La Ciudad de México en los Siglos XVII y XVIII" (2013). Modern \& Classical Languages. 53.

https://cedar.wwu.edu/mcl_facpubs/53 
AVATARES DE LA SUCIEDAD COLONIAL.

LA CIUDAD DE MÉXICO EN LOS SIGLOS XVII Y XVIII

Hugo García

Western Washington University

\section{Introducción}

Los disímiles discursos que fueran producidos en la Nueva España durante los siglos XVII y XVIII certifican la complejidad de los procesos de colonización y formación de la sociedad del primer virreinato del imperio español. Cada uno de ellos muestra un acercamiento particular a la realidad novohispana; muchos de ellos, según su medio particular de expresión y su designio, se acercará de manera diferente a un sistema de valores coloniales asimilados a una escala interpretativa que oscila entre la limpieza y la suciedad. Esta última parece ser una constante de particular valor en medio de los desencuentros culturales que se daban en Nueva España a partir de la convivencia forzada de tres etnias representantes de igual número de continentes.

A la simple mención de la suciedad, automáticamente tendemos a pensar en materia física, que puede invertir el estado de la limpieza o, al menos, alterarlo con su huella. ¿Pero es la suciedad únicamente física? Si solamente de materia física se tratara, ya de por sí estaríamos en una geografía y un tiempo histórico privilegiados pues México fue, por mucho tiempo, azotada por inundaciones cuyas aguas, luego de crecidas no tenían vía de escape que no fuera la evaporación. Las inundaciones -frecuentes por demás y muy seriasalteraban por completo la vida citadina; ellas traían desarreglos de tipo higiénico, y hasta la muerte. No obstante, más que este tipo de suciedad, nos interesa destacar la existencia de tendencias discursivas que asocian elementos sociales, políticos, étnicos y raciales con la suciedad, mientras una contraparte se mantiene en campos contrarios, de la limpieza. Entre estas dos categorías existe, además, la creación textual de un área de contacto, la zona de la polución donde la suciedad se muestra amenazante, o ya ha vencido en sus intenciones de mancillar la pureza con la que se identifican ciertos estamentos sociales, etnias y hasta espacios citadinos de la capital virreinal.

Acerca de los límites temporales —una última puntualización_, la integración de la suciedad en diferentes discursos no aparece en la Ciudad de México en el siglo XVII como tampoco es un fenómeno que finalice por acto de ningún prodigio en el siglo XVIII. En este trabajo no intentamos recorrer el devenir total de la suciedad en todos los momentos históricos de la ciudad; estos son los primeros pasos en los intentos de develar la importancia de la suciedad como una noción prevalente en diferentes discursos producidos durante los siglos de dominación colonial en América. Partiremos en este periplo de la suciedad de la relación que Mary Douglas explica que existe entre suciedad, orden y clasificación para poder articular el uso de la noción de suciedad en la capital novohispana.

\section{Bernardo de Balbuena y la ablución poética}

De entre la innumerable cantidad de textos diferentes que, de una u otra manera, se refieren a la ciudad de México en el siglo XVII, La grandeza mexicana (1604), de Bernardo de Balbuena, es uno de los más conocidos. Si la ciudad misma es el más grande monumento que se levantara al triunfo de España en América, el texto de Balbuena es un homenaje literario al suceso edilicio, con toda la dosis de triunfalismo que requería. En La grandeza mexicana la ciudad es convertida en el personaje único. Pero este personaje-ciudad difiere considerablemente de la realidad de la urbe mexicana de otras evidencias textuales cercanas en el tiempo, cual es el caso de Crónica de la Nueva España (1567), de Francisco Cervantes de Salazar. Dice este autor que "está puesta la población de españoles entre los indios de México y del Tlatelulco, que vienen á cercar casi por todas partes", es decir que admite la existencia de formaciones más o menos circulares dispuestas en orden concéntrico y 
donde el componente indígena es esencial (316). Por el contrario, la ciudad de Balbuena queda recogida en lo que él llamó el "Argumento", donde se cuenta:

De la famosa México el asiento, origen y grandeza de edificios, caballos, calles, trato, cumplimiento, letras, virtudes, variedad de oficios, regalos, ocasiones de contento, primavera inmortal y sus indicios, gobierno ilustre, religión y Estado, todo en este discurso está cifrado. (Capítulo I, 59, el subrayado es mío)

Sobre esta armazón Balbuena se permite recrear una imagen de ciudad como estructura hermética alrededor de los estandartes que perfilaban el poder virreinal y ese 'todo', que hemos señalado en bastardillas, es la clave para entender la enorme carga de subjetividad con la que se elabora la alabanza a México. Cada uno de estos versos constituirá el título de un capítulo del poema, donde abundarán las alabanzas a lo que brilla en la sociedad y la ciudad barrocas, excepto el verso séptimo que no forma en el poema uno sino dos capítulos. Este bifurcar un verso en dos capítulos - el uno dedicado al poder temporal y otro al eje de la organización eclesial colonial - tiene mucho que ver con la condición bicéfala del virreinato y, especialmente, con la aproximación ideológica y el marcado sentido clasista del texto. El sujeto-autor que es Balbuena en el medio virreinal, emprende una carrera por hacerse visible ante los ojos de los centros de poder, aunque su agitado paso dejase huellas de descuido, como bien dice Reyes de La grandeza mexicana que

en el primer original, deben de haber figurado las referencias al virrey entonces actual, el de Monterrey, y a sus ocho predecesores, pero como entre la licencia y la publicación hubo cambio de príncipe el autor resultó necesario juzgar al recién venido [...] sin fijarse, o sin que le importara, que la mención de ese décimo virrey dejaba un poco fuera de orden la mención de "aquestos ocho príncipes" que para ese momento no eran ocho sino nueve. (127-28)

Lejos de las sedes de los poderes político y eclesiástico, los grandes templos, universidad y demás instituciones, Balbuena, entonces visitante en México, ${ }^{1}$ no podría más que sentir marginación, pero "being marginalized cannot be reduced simply to a struggle between oppressor and oppressed in which the latter remains utterly passive" (Gunew 27); la marginalidad propia se resuelve con el auto reconocimiento textual con la cúpula virreinal y el alejamiento imaginario de todo posible contacto con el exterior, plagado de indígenas y cercano al campo -elementos, ambos, contaminantes para el hombre de letras que es Balbuena.

La anulación en el ejercicio poético que es La grandeza mexicana no termina allí. Hay en el Barroco, apunta Maravall, una disposición a fomentar una capa intermedia en la sociedad que permita en primer lugar la existencia definida de una clase superior y luego la de una inferioridad social (283). Esta zona intermedia que en las ciudades americanas era "el anillo urbano donde se distribuía la plebe formada de criollos, ibéricos desclasados, extranjeros, libertos, mulatos, zambos, mestizos y todas las variadas castas derivadas de cruces étnicos que no se identificaban ni con los indios ni con los esclavos negros" (Rama 45). Esta capa intermedia que proliferaba como una necesidad de la ciudad barroca también queda eclipsada en La grandeza mexicana. La ciudad con que Bernardo de Balbuena se identifica queda resumida en los "ricos jaeces, de libreas costosas / de aljófar, perlas, oro y pedrería, / son en sus plazas ordinarias cosas" (Capítulo III, 75). Es decir, en los elementos suntuarios que conforman una imagen denotativa de poder; una fascinación que llega al punto de generar expresiones de complacencia con los "ardientes hornos, donde en medio dellos / la salamandria, si en las llamas vive, / se goza a vuelta de sus vidrios bellos" (Capítulo IV, 80). En otras palabras, aún en las escasas referencias a procesos productivos, estos quedan desvanecidos tras el refulgir del producto final, que son los objetos simbióticamente adheridos a la imagen del poder. Este tomar la superficie sin ahondar detrás del lustre de los materiales más valiosos nos habla por un lado del juego de ilusiones visuales propio del barroco que ya se va forjando, y por otro lado de un pacto de intereses que el sujeto-autor establece con la cúpula dominante. 
Preocupados por la gloria del triunfo hispano y la reproducción de la sociedad nobiliaria en el nuevo continente, los versos de Balbuena se desentienden de todo lo que no es español, para resaltar la heroicidad de la conquista en quienes andan por América "dando a su imperio y ley gentes extrañas / que le obedezcan, y añadiendo al mundo / una española isla y dos Españas" (Capítulo II, 68). Esta "gente extraña" figura por la necesidad de destacar un claro a partir de la contraposición de ese oscuro, o de un conquistador por comparación con un conquistado. O quizás podríamos decir, apegándonos más a un orden cronológico, que esa gente extraña son las extensas masas poblacionales encontradas y que, luego de conquistadas y subyugadas, necesitan ser reducidas nuevamente en el código alfabético; solamente atrapadas en los campos tendenciosos del lenguaje pueden servir como constancia eterna de que quedan fuera del sistema simbólico y aseguran el triunfo imperial sobre los nuevos territorios. Es la masa indígena que queda resumida, al final del poema, en servidora y generadora de los bienes que consume el imperio. Únicamente un indígena es mencionado, cuando dice "que en triunfal carro de oro por él vayas / entre el menudo aljófar que a su arena / y a tu gusto entresaca el indio feo, / y por tributo dél tus flotas llena" (Epílogo, 124). La fealdad de ese indio es el equivalente estético de la suciedad; es lo repulsivo y que se rechaza por contaminante y porque, por sobre todas las cosas, pone al sujeto hablante en tensión. Ese indio tiene que ser separado del centro emblemático; él es la personificación de lo sucio y encarna el riesgo de la contaminación, por tanto debe ser controlado por virtud de su no aceptada condición estética pues, como bien apunta Kristeva, "el peligro de la suciedad representa para el sujeto el riesgo que corre permanentemente el orden simbólico mismo, por ser un dispositivo de discriminaciones, de diferencias" (94). La voz poética se asegura un espacio social, luego de sujetar al indio étnica y racialmente alarmante a lo más bajo de la sociedad novohispana.

Entre los versos de La grandeza mexicana late una batalla entre la realidad objetiva que es la ciudad, a la que se quiere representar de manera laudable, y las características de esa misma ciudad plagada de etnias no aceptadas en la lisonja poética. Esa amalgama poblacional de indígenas, negros y castas, necesaria a la ciudad virreinal, pero innombrable en la superficie marcada por los emblemas, quedarán poetizados en una reducción de contraste que destaca

De sus soberbias calles la realeza, a las del ajedrez bien comparadas, cuadra a cuadra, y aún cuadra pieza a pieza; porque si al juego fuesen entabladas, tantos negros habría como blancos, sin las otras colores deslavadas. (Capítulo II, 71)

Valga aclarar primeramente que estos negros y blancos no habría por qué tomarlos al pie de la letra; está claro que la voz poética pone en juego una reducción pues "es preciso encarar la oposición puro/impuro no como un arquetipo sino como una diferenciación del sujeto hablante como tal, una codificación de su repulsión frente al otro para autonomizarse. La oposición puro/impuro representa (cuando no metaforiza) la aspiración a una identidad, a una diferencia" (Kristeva 111). Así este par de categorías: la de blancos, muy exclusiva que integraría a los españoles y quizás a los criollos descendientes de españoles, y la de negros, mucho más amplia, en la que tendrían cabida todas las pieles más oscuras, incluyendo los indígenas aunque no las castas. Es un juego de luz y sombra en el que asoma la influencia de la naciente estética barroca, y que simplifica la población virreinal, al tiempo que permite no ocuparse de castas, indios o mulatos de manera particular. La existencia en proporción igualable de blancos y negros es una pujante queja bajo el manto poético; una expresión de inconformidad que pugna por salir a flor pero que es contenida una y otra vez a partir de la expresión visual cuadriculada de los claros y los oscuros. El ajedrezado parece sugerir la existencia de una proximidad limitada por líneas separadoras de las razas; quizás un intento de contener en el verso el peligro de la mezcla racial. La incómoda ecuación que genera la igualdad numérica entre blancos y negros se completa "sin las otras colores deslavadas", que serían lo innombrable socio-racial, la zona de polución que cae fuera de toda 
clasificación porque es muestra de la aberración de la sociedad que ha burlado las demarcaciones diferenciadoras.

Ya para inicios del siglo XVII aparece una complejización de la ecuación social que por un lado determina que la porción poblacional entonces denominada "española" es lo suficientemente minoritaria como para considerarse una élite elegida. Pero también esa condición reducida habla por sí misma de la evidente desventaja de este grupo y el peligro de ser contaminado por una mayoría -negra y deslavada. Tras el manto del verbo poético late el sobresalto de la posible invasión de la suciedad sobre la limpieza, es decir el temor al contacto como polución social y, lo que sería más temido, la posible victoria futura de la suciedad que ya se va verificando en la irrefutable presencia de una masa social que no puede ser llamada de otra manera que no sea a través de la impureza, que es, desde posiciones de poder, su única característica destacable. Para desentenderse de esta realidad mestiza, veamos que la ciudad que nos presenta Balbuena es la urbe que se observa desde afuera, desde la distancia. Ciudad acariciada en los versos. El poeta fuerza su pluma a la observación en la altura, al México que se eleva en el plano vertical: "iQue es ver sobre las nubes ir volando / con bellos lazos las techumbres de oro / de ricos templos que se van labrando!” (Capítulo II, 71).

En La grandeza mexicana encontramos la poesía que se circunscribe al mundo de lo estético, sin que exista la curiosidad de la indagación. Quizás porque la poesía, como el mismo autor asevera, es "para no humillarla a cosas rateras humildes" (139), los versos no se adentran en México, en sus esclavos, sus castas y su población indígena. Lo incómodo racial queda excluido, como también aristas referentes a la moralidad social y que, como las pieles oscuras o mezcladas, no conformaban motivo de canto. Por debajo de cúpulas y campanarios que, como jinetes imperiales, cabalgan sobre la ciudad, se esconde otra categoría de lo innombrable, agazapada tras el velo de palabras, y a la decisión de cada quien, que "vea en que rama gusta de enredarse, / que a todas partes hallará corriente" (Capítulo V, 89). Si el silencio es impuesto sobre las epistemes urbanas, el mismo silencio va a marcar diferentes áreas sociales, donde se desarrollan "[...] otros gustos de diverso trato, / que yo no alcanzo y sé sino de oídas, / y así los dejo al velo del recato" (Capítulo V, 93). Estos silencios que se tienden entre los pliegues de la ciudad nos anuncian la existencia de otras aristas de la ciudad que Balbuena, con su subjetividad política, decide no revelar.

Frente a la presencia de la suciedad y de la contaminación causada por el contacto de ésta con lo puro, Bernardo de Balbuena opone la poesía como antídoto. Es en el texto versificado donde Balbuena construye una geografía del refugio que protege del avance de la suciedad. En el "Compendio apologético en alabanza de la poesía" el autor se otorga su espacio propio cerca de los príncipes. Por virtud del ejercicio poético y "por la grandeza de entendimiento que alcanza el que acierta a ser deste número, escogido y entresacado de la comunidad y trulla de los otros entendimientos" (127), su relación con el mundo se hace lírica. En La grandeza mexicana el autor reitera este Olimpo de la gnosis que se eleva por sobre el medio virreinal. Pero este espacio privilegiado al que el poeta siente pertenecer no se perfila por sí mismo, hay que tejerlo con la metáfora y construirlo en la frase ekfrástica. Es así como la voz poética se permite la identificación con la limpieza.

La grandeza mexicana es un texto sobre lo "limpio" imperial, que son los estandartes del triunfo de España y el catolicismo en América. Los elementos arquitectónicos europeos, el orden administrativo virreinal (con sus representantes eclesiástico y laico) y la riqueza de los materiales, son los salientes de un retablo barroco cuyos entrantes quedan en la sombra de lo ignoto del discurso poético. La grandeza de México que se propone en este texto es la línea que marca la silueta de la ciudad creciendo en altura; por debajo nada parece importar, sean las castas, los indígenas, los negros o bien las pulquerías o las inundaciones, o la prostitución, la borrachera y el juego. Todo ello es la suciedad colonial, que empaña los destellos de la pompa y que, por tanto, no tiene entrada en los campos de la poesía.

\section{Sigüenza y su temor a la contaminación con "todo lo que es plebe"}


El disturbio ocurrido en México el 8 de junio de 1692 ha pasado a ser el más conocido por la posteridad precisamente porque fuera recogido por Sigüenza y Góngora. Pero no fue éste el único ni el primero de los desarreglos generales del orden que vio la Nueva España; en palabras del mismo erudito virreinal "no es estta la Ves primera que han intentado destruir a Mexco" (56). Es decir, que en 1692 no era la primera vez que se derramaban los humores del cuerpo virreinal; en 1624 un tumulto se apoderó de la capital mexicana, y vale destacar que en éste resulta distintivo que se oyeran gritos de "inteligibles voces [que reclamaban] viva Dios y el Rey y la R. Auda. [Real Audiencia] y muera el mal Govierno" (Relación del tumulto), pero ello no significa toma de conciencia de la población sobre la idea de separación entre lo divino y lo temporal, entre la corona y el virreinato. Simplemente este parece haber sido un lema contra el virrey, que fuera elaborado desde la sede arzobispal y al que la población sirvió de eco. De cualquier manera ello prueba la latente posibilidad de lo que Moraña llama "la transgresión de las fronteras, la violación del orden, el ataque a la seguridad personal y a la propiedad privada, la invasión de los espacios materiales y simbólicos que constituían el ámbito controlado de la élite virreinal, [...] como una antinatural inversión del estado de derecho" o, dicho de otra manera, una posibilidad de contaminación -que incluye la cabeza política y religiosa- por efectos de la septicemia que recorre el cuerpo social (167).

En Alboroto y motín de México del 8 de junio de 1692, de Sigüenza, llama la atención muy especialmente que, durante la amplísima descripción de los sucesos y a través del desarrollo de la revuelta, hay un especial énfasis en la caracterización de esa vasta gama poblacional que Balbuena, escondido tras el ejercicio poético, intentaba obviar. Para Sigüenza todos aquellos que tenían vedado el acceso al centro del poder virreinal eran, según sus propias palabras, "los Negros, los Mulatos y todo lo que es pleue", pero también los indios a los que fustiga en reiteradas ocasiones y que más adelante veremos (65). Sigüenza, como muchos de su época, no lograba sustraerse ante la impulso de usar la raza como ademán inicial -ya automático en la sociedad colonial- con vistas a la identificación. El erudito criollo, sin embargo, no quedaría satisfecho únicamente con la revelación somática de esa plebe; quizás porque "the Other must be seen as the necessary negation of a primordial identity cultural or psychic - that introduces the system of differentiation which enables the cultural to be signified as a linguistic, symbolic, historic reality" (Bhabha 52). A lo largo de su texto, parece como imponerse la finalidad de exponer a esa población en emplazamientos morales contrapuestos a los propios, estos últimos en alineación con el poder imperial y su representación virreinal.

La posición de cosmógrafo del rey, catedrático de matemáticas y capellán mayor del hospital del Amor a Dios se constituye en triple condición que le permite a Sigüenza construir abiertamente a ese 'otro' que son los planos sociales inferiores identificados con la suciedad virreinal. Veamos algunas de las muy diferentes maneras de caracterizar a la población mexicana. Por ejemplo, cuando dice "la pleue que, diuertida de ordinario en SemeJanttes ocasiones, Se oluida del Comer por aCudir amirar" (53), equivale a decir que esa masa es de dudosa humanidad, toda vez que no responde siquiera a resortes innatos de más pedestre naturaleza, como el comer. Sigüenza repudia el que los sujetos coloniales salgan en masa a mirar porque ello es una manera de apropiarse del conocimiento, además de que ahonda en la caracterización de la población colonial mexicana, diciendo que "En Tan poco Como Estto Se portto bien la pleue y Con alegria, y Con impaciencia y murmuraSion [...] Sin mas fundamento questta Vos Comensó a presumir el bulgo el que mas por Su Vttil que por el della Republica Trattaba en ello" (53). Según Mary Douglas, "dirt is the by-product of a systematic ordering of classification of matter. [...] it appears as a residual category, rejected from the normal scheme of classification" (44-5). Esta suciedad, que a decir de Sigüenza es la plebe, no cae dentro de las relaciones virreinales de poder, no por un sistema de colonización impuesto que le excluye y le convierte precisamente en plebe sino porque, según el hablante, su menguada capacidad de raciocinio no le permite advertir la abstracción que es el cuerpo político y, por tanto, no logra reconocerse en él. Para Sigüenza, hombre de luces, la plebe no lo es porque el sistema político-económico-social la denomine de tal forma y la considere la suciedad social. La plebe es, por el contrario, una condición auto asumida de manera deliberada y, si en algún caso está relacionada a algún factor de tipo causal, ese es un detrimento antropológico de las capacidades racionales de todo lo que 
no fuera la cúpula sociopolítica virreinal. Esta plebe, para Sigüenza, lo es por este primer aspecto, relacionado a la capacidad de intelecto que él mismo le asigna a las capas inferiores de la sociedad colonial, esas que no logran ver, según su criterio, más allá de los límites de sus propios cuerpos físicos, y es ello lo que les mantiene atadas a las innobles manifestaciones de la codicia más pedestre y a las reacciones más destempladas.

El carácter subjetivo y personal del criterio con que opera Sigüenza tiene una segunda parte no menos crítica para el entendimiento de la narración del motín. Dice, por ejemplo, que dentro de esa plebe son "los indios, Gente la mas ingrata, desconoSida, quejumbrosa y inquiera que Dios Crio, la mas favorecida Con privilegios [...] y a cuio abrigo Se arroJa a iniquidades y $\sin$ Rasones y las Consigue. No quiero proSeguir cuanto aqui me dicta el Sentimientto" (54). Por un lado la aproximación paternalista del orden colonial para con el indígena y por otro lado un criterio muy subjetivo parece amenazar con romper los diques de la contención emocional e inundar el texto. Sigüenza deja ver que su posición privilegiada no le permite sentirse seguro, pues en la manera en que describe y critica la población que toma parte en el motín podemos advertir la ansiedad del funcionario que teme la posible pérdida de sus prerrogativas.

Esta ansiedad ante la fuerza de los sujetos coloniales no es privativa de Sigüenza. El fenómeno "plebe" aparece caracterizado en la "Comedia de San Francisco de Borja", de Mathias de Bocanegra, con los siguientes versos: "[...] es tan poco cortesano / el vulgo que la licencia / la conmuta en dasacato" (306). Similar en la relación del padre Abarca por la toma del trono de Fernando VI se tomaran medidas "para estorvar los sinsabores de algun azar del dia de la Jura, y para obviar las contingencias de un fatal acaso, â que siempre están sujetos los Festines donde concurre muchedumbre de gente" (Abarca 26). Es decir que ese "vulgo" o "plebe", o muchedumbre aparecerá como elemento contaminante que habita las áreas del plisado barroco que Bernardo de Balbuena se había impuesto silenciar en su alabanza a México.

La naturaleza misma del texto de Sigüenza y el hecho histórico al que se dedica, justamente uno de los momentos en que la población virreinal hace alarde de su pujanza ante los poderes coloniales, no podía menos que dar crédito a las demostraciones de fuerza que ya eran incontenibles. Un detalle interesante en la relación que hace Sigüenza es la gravedad con que toma su encuentro con artefactos de tipo mágico-religioso; veamos cuando relata que

Se sacó deuajo de la puente de Aluarado infinidad de Cosillas Supersticiosas, hallaron Se muchissimos Cantarillos y ollitas que olian a pulque y mayor numero de Muñecos o figuritas de Varro y de Españoles ttodas y ttodas attraueSadas Con cuchillos y Lansas que Formaron del mismo Varro o con señales de Sangre en los Cuellos Como degollados.

Fue estto ocasión que llegó a Ver aquella obra el Señor Virrey a quien (y despues el Señor Arçobispo en palacio) Se los Mostre. Preguntaronme Vno y otro príncipe que que era aquello; Respondí Ser prueua Real de lo que en estremo Nos aborrecen los indios y muestra de lo que desean Con ansia a los Españoles[...]. (56)

Para Sigüenza las evidencias de la hechicería representan un código incomprensible. La única posible conclusión es, dada la representación antropomorfa, la anticipación del contacto que pudiera producir algún conjuro asociado a la figuración: las efigies y los utensilios son una prefiguración de la interacción de la suciedad con la limpieza, ellos comunican a Sigüenza el contacto que se avecina con ese otro contaminante. Sigüenza, sujeto en perfecta sintonía con la élite, ha encontrado ciertos arcanos de la suciedad indígena, rechazada como un abyecto colonial y ello condiciona una desestabilización que sale por la pluma, precisamente porque

la abyección —encrucijada de la fobia, de obsesión y de perversión- comparte la misma economía. El asco que se deja escuchar en ella no toma el aspecto de la conversión histérica, pues ésta es el síntoma de yo (moi) que, excedido por un "objeto malo", se desvía, se purga y lo vomita. En la abyección la rebelión ocurre totalmente en el ser. En el ser del lenguaje [que] pone mala cara a lo simbólico pero no lo produce, el sujeto de la abyección es eminentemente un productor de cultura. Su síntoma es el rechazo y la reconstrucción de los lenguajes. (Kristeva 64) 
Los modelos de figuración con los que operan los indígenas parecen tener poderes comunicativos, y el hombre de ciencia que es Sigüenza no queda excluido de un mensaje que con certidumbre estremece las áreas de lo intocable colonial que es la élite. La desestabilización ante los objetos encontrados pone al hablante en una crisis que le hace saltar del hecho histórico verificable del cual se había convertido en testigo presencial a la elaboración de conjeturas y de ahí a la fabulación. El mismo Sigüenza se pregunta y se responde: “¿Quién podra desir Conttoda Verdad los discursos en que gastarían los indios toda la noche? Creo que, instigando los las indias y Calentandolos el pulque, Seria el primero quitarle la Vida luego el dia Siguiente al Señor [...] Virrey; quemarle el Palacio Seria el Segundo, haSerse señores de la Ciudad y Rouarlo todo" (60). Parece haber sido atacado Sigüenza por una preocupación de castración simbólica. Ante la desestabilización del avance de la suciedad que es la masa indígena, Sigüenza pasa de observador a fabulador, del discurso que intenta mantenerse dentro de un rango de objetividad avalada por lo verificable a la invención de hechos razonados sobre la base de su propio temor. Solamente la ficción puede hilvanar la historia, y Sigüenza intenta coser la semblanza de la cabeza virreinal que es la suya propia. Se siente amenazado por la revuelta y por ello rechaza a lo sucio colonial que es la masa indígena, pero al mismo tiempo no logra desprenderse de ella, no puede vivir sin ella y la vigila, e imagina verla y escucharla cuando no la tiene ante sí; son los sentimientos hacia lo abyecto, que son de doble valía, de rechazo y atracción (Kristeva 18).

Desde el inicio mismo del proceso de desestabilización a que asistimos, justo en el momento del encuentro de las figurillas y los adminículos de cocina, la solución inmediata de Sigüenza es tan simple que cae en el campo de los instintos: acercarse aún más al obispo y el virrey, personeros claves de los poderes coloniales, posibilidad de auto reafirmación de grupo, como primer paso para intentar romper el hechizo de la suciedad que es la pérdida del control social. Ante la proclama de desestabilización, Sigüenza busca el antídoto de una posible inversión de un proceso de contaminación que ya ha comenzado. En la relación de los acontecimientos según los cuenta Sigüenza, el peligro del contacto comienza por la predicción de la representación de las figuras encontradas. El riesgo no es metafórico, ni siquiera del orden de la mezcla racial. Si Sigüenza da total crédito a las imágenes y las traduce en el deseo de aniquilación de la población que los indígenas sienten es porque en ese atisbo de contacto se pone en riesgo precisamente la integridad de esa capa privilegiada que son los españoles y los criollos descendientes de ellos. Al final, las premoniciones no quedan muy desacertadas, se cuenta en el Alboroto y motín que participó "tantta [...] Gentte no Solo indios Sino de todas Casttas, tan desenttonados los Grittos y el alarido, tan espessa la tempesttad de piedras que llouia Sobre el Palacio que exsedia el ruido que hacian en las puertaz y en las benttanas al de mas de Sien Caxaz de guerra que Se tocasen Juntas" (65).

\section{La mojiganga o la polución permitida}

Durante los siglos XVII y XVIII, marco temporal de este trabajo, los poderes virreinales se debaten entre la necesidad de la presencia del vulgo y el deseo de la exclusión, entre una separación antiséptica y la necesidad de mezclar los elementos sociales racial y clasistamente contaminantes. En momentos de celebraciones y actividades masivas la presencia de todas las capas poblacionales, incluyendo los indígenas, negros y castas, se convertía en un requisito de los poderes coloniales del virreinato que se veían urgidos de autoconstruirse una imagen de fortaleza y arraigo que solamente la población podía ofrecer. En estos días en que el poder moldea su propia imagen, la presencia de la población indígena, los negros y las castas no siempre denotaba suciedad; la proximidad no era anuncio de peligro de polución y la amenaza al orden virreinal era obviada. Para Sigüenza el peligro es "la plebe". Alboroto y motín es una llamada de auxilio a contener a esa misma población, que es construida textualmente como peligro contaminante. Sigüenza no logra silenciar a la plebe, ni siquiera lo intenta-, por dos razones fundamentales: primero él es parte innegable de la élite virreinal, y segundo su propio temor no le permite quitar la vista de esa masa peligrosa. La polución significaría para Sigüenza la pérdida de las prerrogativas del sujeto blanco criollo, que se identificaba con lo español. 
En los días de celebraciones, cuando la eficacia de la imagen tocaba sus puntos más altos, "native elite always performed their official identity as individuals whose ancestors had been subjugated by the Spanish during the Conquest. This point was emphasized by the manner of dressing in pre-Columbian festival clothing and the fact that they always spoke publicly in Nahuatl" (Curcio-Nagy 49). Quiere decir que esa plebe tiene otra significación, pues la presencia indígena era enfáticamente mostrada como parte de la retórica imperial que necesitaba de la representación del buen vasallo para oponer un punto inferior a la superioridad española, blanca, de ascendencia nobiliaria. En esta representación de la sociedad lleva impresa la aseveración del triunfo de un sistema de inspiración divina sobre lo mundano, lo que equivale a decir el entender la sociedad como un retablo barroco, oponiendo lo elevado a lo bajo.

"El Barroco, en todos los aspectos que integran esta cultura, requiere un movimiento de acercarse a las masas populares; de ahí que, sin perjuicio de la variedad que ofrezcan los recursos de que se valga, pretendan siempre, quienes los manejan, trascender con ellos del círculo de la minoría aristocrática" (Maravall 203). Bajo este presupuesto, es puesta en funcionamiento durante los siglos XVII y XVIII la presencia masiva de los sujetos de las ciudades virreinales. Los indígenas eran traídos a las exhibiciones en las que el poder convertía las procesiones, como representación estratégica del vencido y el adoctrinado, así mandaban en muchas ocasiones que "para ornato de la processión se procurasen hacer algunos arcos de yervas (como en esta tierra acostumbran a hacer los indios)" (Morales 4). Como resultado, el engalanamiento de la ciudad se bifurcaba en imágenes que pudieran parecer provenientes de diferentes lugares o tiempos, porque junto a la arquitectura efímera de inspiración clásica, con dioses grecorromanos e inscripciones en latín, se podían ver otras estructuras revestidas "con muchas sedas, estandartes, gallardetes, rosas, flores, frutas, conejos, aves vivas y rica plumería" (70-71). En esta convivencia de códigos ornamentales de diferente procedencia se evidencia un desencuentro que apunta a la imagen de la ciudad en procesión como una yuxtaposición de claves disímiles que son conectadas únicamente por la mirada del observador que relata la festividad. Desde nuestro punto de vista, detectamos la curiosa combinación del rechazo a lo no blanco (indígena o negro), excluido porque no constituye estamento de poder ni de civilización, con la necesidad política de la presencia de esos mismos elementos contaminantes.

Las festividades llevadas a cabo en México, en 1747, por la exaltación al trono del rey Fernando VI fueron recogidas en el texto titulado El sol en león. Cuenta el padre Joseph Mariano de Abarca, autor de esta relación, que los negros y las castas también fueron llamados, como ya venía siendo acostumbrado, a ofrecer sus muestras de lealtad. Dice el religioso que éstos interpretaban "el desposorio de no sè que personages, por lo que festejaban tan varias naciones, como instrumentos, resonando à vn tiempo castañuelas de Españoles, sonajas de Mulatos, bandurrias de Mestizos, ayacaxtles de Indios, y zambra de Negros", en una encrucijada de códigos culturales tan disímiles que el mismo autor, siendo testigo presencial, queda un tanto confundido (21V). Por un lado, él logra entender las razas y asociar los instrumentos musicales a una lógica pseudo-etnográfica. Sin embargo, cuando tiene que decodificar la performance como un todo se queda imposibilitado de racionalizar la información. La superposición de razas, instrumentos y sonidos resulta una mescolanza ininteligible; es la polución social que escapa a las explicaciones de la racionalidad colonial. Expresiones como éstas resultan frecuentes en los documentos publicados con motivo de las conmemoraciones que movilizaban a la ciudad por la importancia que para la cúpula político-religiosa reviste la participación de la masa total de los individuos de la ciudad y sus alrededores. En palabras de Maravall, "el Barroco pretende dirigir a los hombres, agrupados masivamente, actuando sobre su voluntad" (275), por tanto los indios, negros y castas disímiles no representan la suciedad y su proximidad no activa ningún resorte de pánico pues "festivals were pervasive, a defining characteristic of the life in the capital" (Curcio-Nagy 2). Estas festividades construían la imagen del poder, y en cada una de ellas era requerida la presencia de la población general de la ciudad y aún de las áreas circunvecinas.

En estas festividades públicas aparece la mojiganga, con su especial atractivo para nuestros intereses pues resulta otra ruptura contaminante al centro de la gravedad de las procesiones virreinales. Pongamos por caso que, no muy lejano a tiempos de Balbuena, en 1672, y en la misma ciudad de México, se celebró una fiesta 
en honor de San Francisco de Borja que, como todas las solemnidades religiosas de la capital novohispana, iba cargada de la severidad de la reverencia y el boato. En pleno desarrollo de la procesión, según nos cuenta el narrador testigo, el día

Iveves onze de Febrero, sucedieron las burlas á las veras: y tomaron tan de veras las burlas los cursantes de el Collegio de San Pedro, y San Pablo de la Compañía de IESVS, que passaron de quatrocientos los enmascarados: pero la misma multitud de inventiuas burlescas sobre ingeniosas, causó vna tumultuaria, aunque festiua confussion (Festivo Aparato 17, énfasis mío)

Muy sucinto, en este fragmento que narra el momento inicial de una de las jornadas de la festividad organizada por los jesuitas, encontramos el punto de viraje que sufre la ceremonia. Los estudiantes del colegio jesuita crean, en el plano visual, su propio discurso satírico a partir de la exageración como una de las categorías que mueven a risa. Con el aumento inesperado del número de enmascarados que solían aparecer en estas fiestas bajo denominación de "mojiganga", los estudiantes no sólo sorprenden a los observadores, sino que también convierten a la celebración de la Compañía de Jesús en su propia parodia. La contaminación en esta mojiganga comienza con el revoltijo de códigos expresivos: la mesura y la severidad tienen que convivir con el descontrol y el descomedimiento.

En este caso las costumbres establecidas para este tipo de celebración -y que el narrador llama "veras"- son quebrantadas por la exageración como mecanismo satírico, y que vendrían a ser las "burlas". "Veras" y "burlas" conforman para el autor del texto que relata esta festividad un par de opuestos, el uno positivo, el otro negativo; la primera categoría anda por el camino ya abierto, el de lo establecido, mientras que la segunda establece una nueva vía, e irrumpe con tal fuerza que empuja fuera a la primera -"las veras"- para tomar su propio espacio. Una convivencia de opuestos que resulta peligrosa tanto que anuncia la posible contaminación. La mojiganga, por tanto, subvierte el sistema que es el lenguaje sobrio y formal del discurso oficial y pone en su lugar la desmesura, la informalidad y la ligereza como contradiscurso. Pero esta mojiganga no termina aquí. Veamos además que los discípulos jesuitas no sólo alteraron el número de enmascarados acostumbrados en las fiestas; ellos también incluyeron en la procesión

vna turba multa de atabaleras, que según las señas, tenian algo, y aun algos de locas, se avian soltado de el célebre Hospital, donde se curan con xaraues de rebenques los males de cabeça [...] Todas iban en borrico, por no decir á caballo [...] que por olbidar, ó desmentir su delirio, lo echaban á las espaldas en rotulos de muy buena letra: pero correspondientes a los desatinos que les trastornaban las cabeças: El de la atabalera, que iba passando su vida en tragos, empinando á trechos lo que ella se sabía, y le sabía, era este LA DEVOTA: El de la que retrataba la misma senectud, dezia: LA NIÑONA: en el de la mas fea, se leia: LA LINDA: En el de la mas abobada: LA DISCRETA. (Festivo aparato 17R)

La intervención de la demencia por acción de los estudiantes no quedó en la representación femenina porque también aparecieron los hombres no menos dementes y cargando sus carteles en las espaldas. Veamos únicamente el caso del que cargaba una pancarta que decía:

\section{EL VIVDO}

Por viudo, con porfía

Procuro a Borja imitar:

Mas como el, no puedo hallar

Vna buena COMPAÑÍA. (19)

Con esta irrupción, la demencia hace un corte en la diacronía de la celebración: la solidez de la gramática visual de la festividad es permeada por el elemento ruidoso y desordenado de la demencia. Al incluir este elemento totalmente externo y opuesto a la pompa virreinal, los estudiantes no incluyen una simulación de anomalía sino la anomalía misma y ello a su vez genera una hibridación que, como bien reconocen Stallybrass y White, produce nuevas combinaciones significativas al crear grietas en la coherencia semiótica del discurso del 
poder virreinal (58). Es decir que la ficción de los cuerpos falsamente anómalos o ilusoriamente ordenados bajo la marcialidad del ejército, es sustituida por los cuerpos afectados por la demencia real; los falsos elementos de la mojiganga que respondían en todo momento al despliegue del orden virreinal han perdido su carácter teatral y ahora ponen en peligro la imagen de ese mismo orden. La simulación de lo contaminante es sustituida por el elemento contaminante mismo que es la locura.

Como receptor de la acción de esta mojiganga se encontraba una concurrencia observante que no queda caracterizada en el documento, imaginamos que posiblemente una amalgama representativa de la población virreinal con diferentes emplazamientos en sus relaciones con el poder, en estratos alejados en mayor o menor medida del círculo dominante. La propia ubicación en la celebración nos dice que estos son sujetos con un acceso muy tímido al poder, si no nulo. No obstante, y a pesar de las diferencias entre sí y su distancia con el poder, estos sujetos responden de manera uniformada ante la irrupción de la demencia. El autor del Festivo aparato relata que las dementes aparecen "asustando todas, y no poco a muchas damas de aquel gentio", mientras a los hombres "cada cual les procuraba dexar el campo franco, y ellos mismo se lo abrian, ya con las mas bellacas bestias, que aposta buscaron, ya con las mejores, y los mas fornidos garrotes, que pudieron auer á las manos" de lo que se infiere que estos sujetos observadores establecen una relación con la demencia que abre otra arista de la carnavalización (17V, 18V). Lo que Peter Stallybrass y Allon White han llamado displaced abjection y que explican como "the process whereby 'low' social groups turn their figurative and actual power, not against those in authority, but against those who are even 'lower"' se cumple en esta celebración mexicana cuando la población observadora huye de la presencia y los ademanes descontrolados que provoca el desequilibrio mental (53). Al ratificar la inconveniencia de la demencia los asistentes se distancian de los desatinos de la enfermedad mental para consolidar su propio estrato social en el discurso visual de la fiesta, aún por debajo de la cúspide del poder virreinal pero por encima de la demencia - que marca el límite de lo intocable, de la suciedad-. Esta actitud trae como resultado vínculos entre el poder y los que quedaban desplazados de él, los que ahora en plena celebración callejera se auto-adjudican una posición simbólica superior que le permite identificarse con el eje del poder. Es decir, que en la pirámide social colonial siempre hay un 'otro' que es inferior porque es asociado a lo bajo y lo sucio, trascrito como agresivo y contaminante. La caracterización de ese 'otro' es parte esencial en el proceso de definición de un 'yo' hablante que se (auto)ubica siempre en posición de ventajosa superioridad.

Muy relacionada a la demencia que antes vimos, se presenta en esta fiesta otra muestra inesperada de lo excluido por la oficialidad, y al desatino que mostraban las imágenes corporales que exhibieron las dementes se unió

otra loquilla de pocos años, y de tan buen gusto como gesto; esta (por no ser de dos caras como las demás de su séquito) primorosamente afeytada, y ricamente vestida, ahorrò totalmente la mascarilla comun, engañando a todos con la misma verdad de su cara lavada. Era estraño lo mesurado de su rostro en las cortesias, y tan singular su gravedad. (18R, énfasis mío)

Hasta este momento tenemos en el fragmento que el autor se siente incapaz de descifrar la imagen y queda él mismo engañado -incomunicado- como el resto. Esto hace que quien relata se tenga que conformar con describir la desconexión de esta imagen con las que transmiten el resto de las mujeres dementes, porque es el único punto concluyente a que su desconcierto le permite arribar. No es sino después de una reevaluación de la información visual, que el autor logra descifrar que quien tenía ante sus ojos era un "mancebito relamido, y en tan romance afeminado" (18). Demencia, travestismo y homosexualidad son tres expresiones antagónicas al discurso eclesial, por tanto contaminantes dentro de la procesión. La polución que resulta de la inclusión de la mojiganga crea un relajamiento que, además, atrapa la atención de aquellos sujetos coloniales aún forzados a deambular los espacios sin estar completamente interesado. Esta identificación de la población a manera de complicidad contra-discursiva es un control que ejercen los poderes coloniales a través del humor. 
La mojiganga en sí podía tomar muchas formas; veamos otro caso, en medio de la anteriormente mencionada festividad mexicana de 1748, por la toma de posesión de Fernando VI. Encontramos entonces que desfiló

una Marcha â la Mojiganga, compuesta de quarenta hombres, con sus Oficiales, y Cabos, y el Alférez con su Vandera, cubiertos con Mascarillas, y vestidos todos de Uniformes de petate, $[. .$.$] los cuales marchaban al son de la Caxa de Guerra, y Pifano, con gran orden por$ todas las calles de esta Ciudad, armados de Geringas por Fusiles, y haziendo alto en varias partes, y principalmente junto â Palacio, hacian ejercicio, dando al tiempo de decir: Disparen, tal carga cerrada de agua, que parecia un espeso aguazero. (Abarca 263)

Nuevamente aparece una diversión burlesca, como la sección de la procesión que más se alejaba de la representación elevada y del boato, pero no por ello llevaba una intención ideológica menos eficaz que el resto de las representaciones que aparecían en la procesión. Teniendo en cuenta que en el medio barroco "todas las cosas son movibles y pasajeras; todo escapa y cambia; todo se mueve, sube o baja, se traslada, se arremolina" (Maravall 371), no resulta demasiado notorio que la seriedad de la festividad por momentos fuera trocada en una pizca de humor que creaba esta inclusión de representaciones semi-monstruosas o burlescas, para luego regresar a la dinámica de la severa representación del poder con toda su simbología. La mojiganga pone de manifiesto la importancia otorgada al manejo de la imagen durante la época barroca y la manipulación de la imagen por parte de los poderes coloniales. A este constructo de la apariencia se suma la mojiganga que, aunque corrupta y ruidosa a primera vista, no tiene nada de superficial o impensado: la liviandad de este divertimento era únicamente su fisonomía más externa. Debajo de estos enanos, cabezones, barrigones, agigantados y falsos soldados estaba la seria intención ideológica de captar la atención de los que quedaban excluidos, no sólo de la participación político-económica, sino de la posibilidad de identificarse con las alegorías y los símbolos que inundaban los espacios urbanos durante la celebración, tanto como con la exhibición desmedida de riqueza en ropaje, joyería, carrozas y caballos.

La mojiganga era la figurada concesión que el poder hacía a los estratos menos favorecidos y el gancho que atrapaba a estas clases bajas y las integraba a la festividad pues "no todos, ni mucho menos la mayor parte de los individuos y aun de grupos sociales enteros, podían participar en ese goce cultural, precisamente por las condiciones sociales inferiores, de pobreza y subordinación en que se hallaban" (Maravall 195). De manera que estos estratos, a través de la mojiganga, lograban ver en la procesión una imagen que de alguna forma los hacía sentirse parte del centro focal que era la procesión. Al imantar la atención en el centro de la celebración de toda esta masa humana de indios, negros, mulatos y las castas infinitas que vieron las ciudades virreinales, y que constituían una mayoría numerosa y peligrosa y así lo habían demostrado en los motines, se les ofrecía una cierta distracción que garantizaba el necesario control sobre ellos (72).

La mojiganga, lejos de ser una fractura en la severidad, es el instrumento que garantiza a los estamentos en el poder la posibilidad de extraer a las masas de sus problemáticas particulares y traerlas a la celebración bajo la ilusión de la de una participación activa en los funciones de la ciudad virreinal. Este nivel participativo de la mayoría es únicamente una ilusión construida de manera epidérmica que se circunscribe a la presencia física en la celebración; con ello se reafirmaba por demás la centralidad política de la sociedad barroca virreinal. Demencia, homosexualidad, travestismo, fealdad y vejez, entre otros, son componentes residuales de la sociedad virreinal y su sistema clasificatorio. Son las cualidades consideradas antítesis de los parámetros de comportamiento y las características visuales consideradas positivas para la construcción de la imagen tan cara a los hábitos de cortesanía forzosos al injerto imperial que es la capital de Nueva España. Son los componentes de lo interdicto colonial, la suciedad en la sociedad, que es traída al primer plano por una necesidad política, pero su convivencia con las normativas del comportamiento virreinal es controlada por la misma sintaxis de la celebración. Ni la suciedad es aceptada, ni la contaminación es aplaudida. La mojiganga en sí no constituye un atisbo de carnavalización de la ciudad virreinal ni de sus festividades pues, en primera instancia, es jocosidad 
que no tiene espontaneidad, por lo que no provoca alteración del orden virreinal; ella queda perfectamente prevista como parte de la diacronía de la procesión misma. Los indicios de carnavalización que aparentemente muestra la mojiganga estaban proyectados para rendir frutos efectivos a la élite político-religiosa. En otras palabras, lo que de formalidad pierde la celebración con la inclusión de estas monstruosidades y falsos soldados, lo gana la élite en distracción ideológica y adhesión de los bajos estratos. La mojiganga es, en suma, la polución figurada; un elemento representativo de la astucia política colonial.

\section{La pintura de castas; la polución colonial en el lienzo}

La mezcla racial es una de las más tempranas de las rupturas que sufre el sistema colonial ibérico en la América hispana; un sistema que asumía inicialmente -quizás de manera bastante ingenua- que cada sujeto, según su raza, llevaría el membrete de su ubicación social. En el siglo XVIII aparecen los cuadros de castas para demostrar que el orden social inicial había sido violado con la mezcla entre las razas pero, sobre todo, que la complejidad a la que había llegado la mezcla racial a partir de sus tres componentes iniciales -español, indio y negro- hacían a la sociedad novohispana una masa prácticamente ininteligible. Es precisamente en la mezcla racial donde la pintura de castas pone su énfasis; es un inventario de males que nacen de la mezcla como espacio antropográfico de contacto entre las partes "puras", contaminación que ocurría, y había ocurrido, por al menos dos siglos. Las castas tienen entonces una doble significación: ellas son primero los consumidores de este espacio intermedio, impreciso, donde la lógica colonial se nubla y se difumina. A la vez son las castas la prueba de la existencia y complejidad de esa zona que pugna por desprenderse de la dominación imperial sobre los sujetos coloniales y que, en retribución es considerado por el poder como la zona social de la polución, de lo que escapa a toda posible clasificación porque, como bien explica Cope, "the castas had no preassigned place. They were not Spanish 'citizens' (vecinos), nor could they claim the legitimacy of the land's original inhabitants. In short, the casts were an anomaly" (15).

Las castas son puntos a mitad del camino, donde lo blanco y lo negro, lo español y lo indígena se diluyen para crear un estado polución racial que en el contexto hispanoamericano colonial se refleja en lo social, lo político y lo económico. En palabras de Mary Douglas, "caste pollution represents only what it claims to be. It is a symbolic system, based on the image of the body, whose primary concern is the ordering of a social hierarchy" (154); y es que en las antiguas colonias hispanas el contacto físico de los cuerpos biológicos de diferente coloración es indicador de conectividad entre estamentos sociales que debían mantenerse separados. Es decir, que si llegan a constituir un sistema simbólico es de forma forzada, resultado de la existencia de una contaminación que, en primara instancia, no debió haber ocurrido. Frente al hecho contaminante y su prueba material (las castas), los cuadros que conforman estas series plásticas vienen a intentar, en primera instancia, una explicación que se inicia en la deconstrucción histórico-social de la mezcla racial de manera diacrónica. Ante la promiscuidad racial, las series de pinturas de castas resultan un documento esencial que por un lado critica, es cierto, el mal funcionamiento del sistema colonial impuesto, pero también actúan en beneficio de ese mismo orden, a manera de intento de recuperación de ese lugar que ha caído en crisis. Las pinturas de castas, más que una ingenua representación o un puro ejercicio plástico, son un instrumento al servicio de ese ordenamiento social inicial.

En la segunda mitad del siglo XVIII ese lugar privilegiado que había sido determinado para el grupo español, más que una realidad, era una interrogante que genera la aparición de los cuadros de castas como una declaración político-social porque presenta al negro o indio (los contaminantes), como el agente agresor. Es la suciedad la que invade la pureza y crea la polución. Para intentar recobrar esa posición especial de la raza española, las series de cuadros de castas establecen una línea por la que han de andar las diferentes mezclas, cargando cada una con su nivel de polución según la mayor o menor distancia a las fuentes de la suciedad negra e india. Aparentemente en el proceso de blanqueamiento que registran las series de castas, hay una posibilidad de redención pues las generaciones coloniales van limpiando las marcas más evidentes de la mezcla 
racial hasta llegar a castas de apariencia más blanca, como la "castiza" y la "gente casi blanca". Parecería que hay posible vuelta a los inicios, como si se tratara de una trayectoria circular. Sin embargo, el círculo nunca llega a cerrarse nuevamente, porque las castas son castas por muy pálidas que se presenten, y por ello nunca vuelven a ser "españoles". Es una reelaboración de lo interdicto racial y por ello las castas no podrán acercarse nunca a la línea reservada para una minoría que se aferra a retener indefinidamente el control colonial. Para mantener la integridad del cuerpo político virreinal la pintura de castas intenta establecer un derrotero para canalizar la polución que ha resultado del contacto con la suciedad. Al etiquetar las castas, las series pictóricas están creando una nueva raza que es precisamente la polución, que debe ser dominada y controlada como en un inicio se supone que debió haber ocurrido con las razas no españolas -entiéndase la india y la negra.

Las pinturas de castas es una producción cultural que se encuentra en la encrucijada de, al menos, tres influencias esenciales. Por un lado, la generalidad de estos cuadros se basan en la representación de la sagrada familia, una tradición ya para entonces muy antigua que es ahora resignificada. La trilogía madre-padre-hijo servía como estructura perfecta para determinar los componentes de esta nueva problemática que es la mezcla racial que ha ido dándose por generaciones en los territorios coloniales. Por otro lado la tradición retratista que llega de Europa también se hace sentir en las representaciones de las castas novohispanas, no para inmortalizar al sujeto sino para inmovilizarlo en su relación con el entorno socio-político, al igual que en los retratos por medio de símbolos y/o metáforas que caracterizan al personaje representado. Y, por último, el interés por una codificación visual de "lo americano", que se desarrolla fundamentalmente en el grabado y que da la vuelta a Europa como parte de la información recogida en libros y en la cartografía.

Uno de los cuadros más interesantes de cuantos fueran producidos en el México del siglo XVIII es el conocido como De alvina y español produce negro torna atrás (Fig. 1).

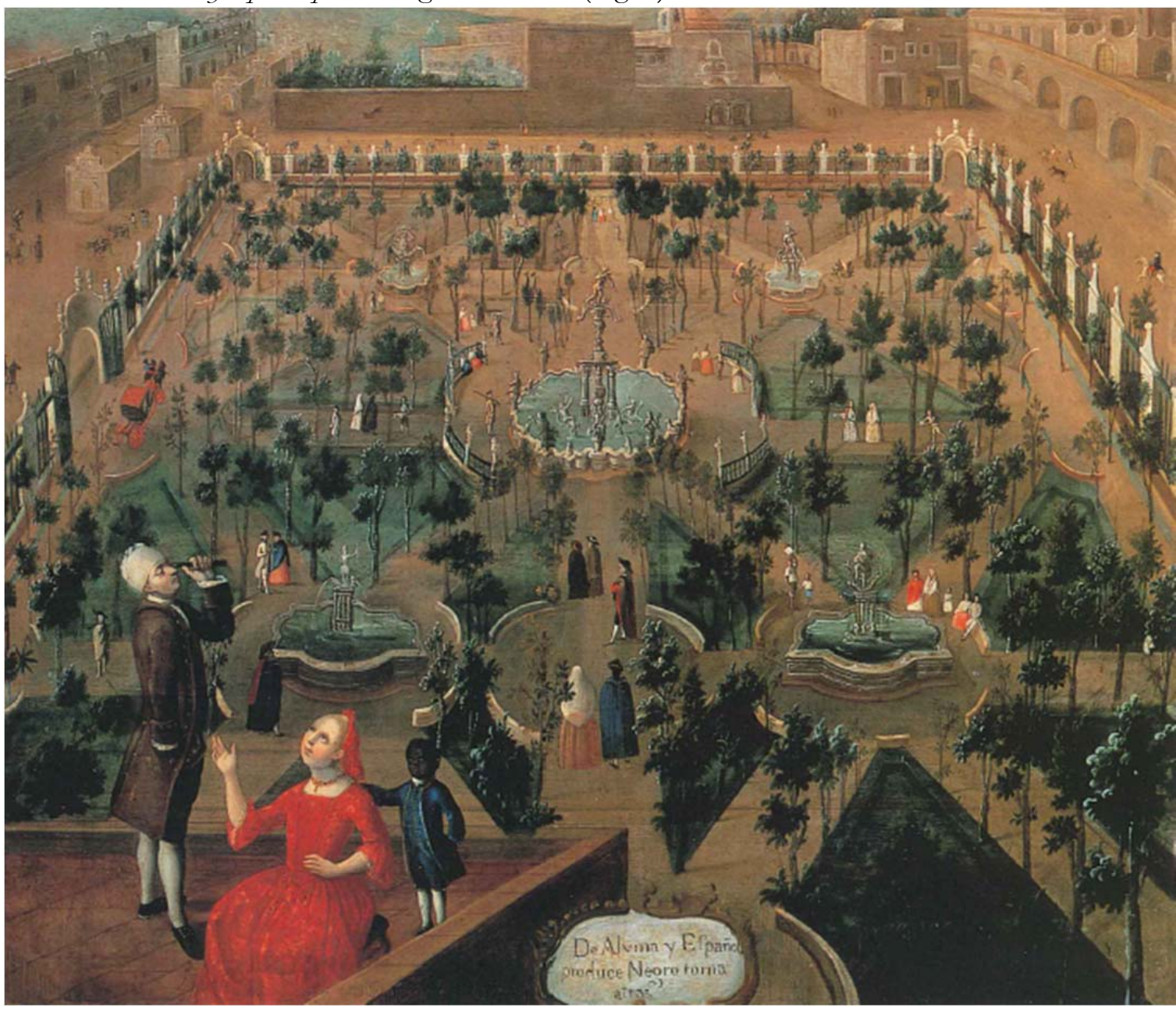


Fig. 1. Anónimo. De alvina y Español produce Negro torna atrás. Siglo XVIII. Óleo sobre lienzo. 46 x $55 \mathrm{~cm}$. Colección Banco de México, S.A.

Este cuadro es uno de los mejores exponentes de la intención de la pintura de castas de representar a los sujetos coloniales en su relación con la sociedad a partir del distintivo racial. En la obra, como ocurre generalmente, se nos presenta una tríada madre-padre-hijo pero con una particularidad interesante: la familia ha perdido su lugar al centro del cuadro. Una vez empujada la familia a los márgenes del soporte, la relación fondo-figura queda distorsionada. Al abrir el campo visual de la representación, el centro viene a ser ocupado por uno de los espacios emblemáticamente más reconocidos en la ciudad de México: la Alameda que, lejos de ser el fondo en el que se ubica la familia, ha pasado a ser la figura representada; la familia, entre tanto, con su ubicación esquinera y su disminuida dimensión viene a ser un elemento más en la composición. Es decir que, desde el punto de vista técnico, el cuadro que analizamos diluye un tanto su propia deuda con las tradiciones pictóricas del retrato y la sagrada familia; al parecer el artista estaba más interesado por la representación de lo que no se pintaba con suficiente claridad, que eran las relaciones coloniales que mantienen las castas con el poder a través de la metáfora visual de los espacios emblemáticos.

De alvina y español produce negro torna atrás nos presenta a una familia obligada a ocupar una azotea, alejada del espacio de distracción pero también del centro de la exhibición social de los sujetos durante el Barroco. Poco importa que el padre sea español y que la madre sea albina; la familia en sí es una remembranza de la polución social que se crea con el contacto (sexual) entre las razas. Las transgresiones de los límites socioraciales quedan excluidas de los espacios que son el eje físico del poder colonial; a las familias como ésta solamente les queda conformarse con el disfrute visual en la distancia. El referente espacial se enfatiza como inalcanzable y se fetichiza aún más con el catalejo del padre (español) que solamente puede participar del centro con el acercamiento que las lentes le permiten. Como indica Kristeva, "la impureza es un mal objetivo padecido por el sujeto. O dicho de otro modo: el peligro de la suciedad representa para el sujeto el riesgo que corre permanentemente el orden simbólico mismo, por ser un dispositivo de discriminaciones, de diferencias" (94). Ante el peligro de la contaminación, la pintura de castas parece querer intentar detener la mezcla y crear un eje separador que clama por la purgación de los espacios exclusivos.

En la generalidad de los cuadros de castas el elemento más importante es el hijo, centro indiscutible de la atención de los cuadros de castas porque es la respuesta a la interrogante que surge a partir de un nuevo cruce racial. En el que analizamos, sin embargo, la atención está dividida. Por un lado aparece el hijo, que es un "torna atrás" - la mejor de las castas para la representación de la suciedad, pues su piel es muestra cromática de lo más oscuro en la gama de las posibilidades humanas. La oscuridad de la piel del vástago trae al primer plano al componente negro, raza que es convertida en la suciedad en el código de la representación plástica. Si el hijo vuelve atrás es para recordar que la palidez de la madre no es sinónimo de pureza sino de una polución familiar que no por disimulada puede ser obviada. Esta impureza familiar no es, empero, privativa de la madre (de casta albina) ni del hijo; también es del padre cuyo cuerpo, aunque español, ha entrado en relación directa con la madre que no es pura. $\mathrm{Y}$ es que para el poder colonial la sexualidad resulta un obstáculo y por tanto se convierte en un fetiche. En este cuadro de castas que hemos tomado como ejemplo, la ambigüedad se reduce, la anomalía queda físicamente controlada y evitando la anomalía que es esta familia mezclada, se logra reafirmar y fortalecer aquello a lo que la anomalía no pertenece (Douglas 48-9). Las prácticas sexuales son el área más privada de los sujetos coloniales, y es precisamente este carácter íntimo lo que exacerba el deseo de control del poder colonial, que quiere entrar en las alcobas y filtrarse bajo las sábanas. Si por un lado, entonces, tenemos que el hijo es la rememoración de la suciedad, en el extremo opuesto de la escala se presenta la Alameda, como el espacio de la pulcritud, allí donde -al menos en teoría- debía moverse esa área de la población que podía ser catalogada de pura, una élite que en Nueva España era de alrededor del 15\% de la población general (Hoberman-Socolow 24). Una élite que, detentando el poder, también mostraba su inseguridad. La pintura de castas, y muy en especial este cuadro que analizamos, se hace eco de este orden con una marginalización de tipo 
doble: si la familia es excluida de los espacios centrales de la sociedad, asimismo debe ser esta familia llevada al margen del soporte pictórico. En este caso el hijo ha completado un ciclo en reverso, trayendo al presente el componente negro de la genealogía materna. El "negro torna atrás" parece ser un llamado al reconocimiento de la suciedad que deambula por las calles de la ciudad imperial que quiere ser México a la vez que es un reclamo de regreso a la ordenación inicial de la sociedad novohispana a través de lo somático-social.

A través de una clasificación de basamento pseudocientífico, las representaciones de las castas ponen en juego un esquema matemático que determina la relación entre los componentes raciales, una proporción de tipo inverso entre dos componentes fundamentales: la pureza y la suciedad. La cantidad de castas varían según el pintor que realice la serie, pero entre ellas hay una constante: más que una simple representación de los cruces raciales y el resultado de ellos, los cuadros de castas son una carta de navegación social que fijan una cantidad de calidades de sujetos, como elementos contaminantes coloniales, y su procedencia. El surgimiento mismo de los cuadros de castas constituye un grito visual del fracaso de un orden social impracticable que fuera ingenuamente pensado a partir de los rasgos fenotípicos. Ya dentro de los mismos cuadros tenemos al sujeto despojado de toda posible diligencia: el sujeto es delineado a partir de una cadena de significaciones que tiene su inicio en la raza, sin tener en consideración las diferentes posiciones que dentro de las relaciones de poder pueden ocupar individuos que racialmente pertenecen al mismo grupo. La pintura de castas se convierte en un instrumento de poder porque intenta racionalizar la impureza colonial. Frente a la polución observada, la pintura de castas se posiciona junto al dominante y rehace la historia de la capital novohispana a través del contacto de los cuerpos de sus sujetos coloniales. La pintura de castas propone una nueva falacia imperial.

\section{El ciclo de la suciedad}

En las páginas precedentes hemos intentado descubrir algunas de las manifestaciones de la suciedad en la capital novohispana durante dos siglos de la época colonial. Así hemos partido de la imagen inmaculada de la urbe triunfante que recibimos en La grandeza mexicana, para llegar al sujeto colonial manchado por la mezcla que nos presentan las pinturas de castas; de la pureza y el orden de la clasificación sistemática a la promiscuidad de las razas. Hemos asistido a la representación de la ciudad como cuerpo urbano, cuya altiva cabeza de "religión y estado" va acompañada de un cuerpo engalanado de riqueza material, y hemos terminado en la entidad biológica que es el cuerpo físico del sujeto, en sus relaciones sexuales con otros y, lo que es más interesante, en las castas disímiles que son la referencia sugerente al resultado de esos encuentros carnales (Balbuena 59). El orden del recorrido no es una casualidad imprevista; en este acápite, que ya viene a ser el último de este trabajo, queremos acercarnos aunque de manera rápida a la importancia del cuerpo biológico que, productor de suciedad, queda íntimamente ligado a los desarreglos ideológicos.

Es cierto que, como afirma Kristeva, "la impureza bíblica es siempre una logificación de aquello que va contra lo simbólico [...]. Esta logificación inscribe lo demoníaco en un registro más abstracto, más moral, como una potencialidad de culpabilidad y de pecado" (123). Sin embargo, en medio de la urbe virreinal el proceso no se encamina hacia la intelectualización de la falta sino hacia la vulgarización de la misma, hasta el nivel más elemental posible. Ese nivel es el cuerpo. El Santo Oficio intenta la comunicación con una masa poblacional amplísima y, sobre todo, muy heterogénea y para hacer que el mensaje atravesara todas las variantes de la sociedad colonial, trae el pecado de vuelta: desde los niveles bíblicos más abstractos hasta el cuerpo. La falta a la moral religiosa impuesta es convertida en suciedad; una suciedad que es práctica corporal repudiada por la mayoría recipiente del discurso aleccionador. Es en el rechazo a esa suciedad donde el Santo Oficio sienta la justificación de su existencia. A través de la suciedad como hecho físico, resultado de la fisiología, pueden ser establecidos los lazos entre ambos planos -el de la moralidad abstracta y el físico de la corporeidad. El cuerpo material se reproduce y amplifica, en muy diferentes espectros políticos, sociales y religiosos. Muy relacionada al 
cuerpo biológico de los sujetos coloniales, encontramos a la Inquisición, que sacudía la sociedad virreinal con bastante periodicidad, y que funcionaba como una institución sanitaria cuya labor intentaba ser profiláctica y, por tanto, se empeñaba en hacer desaparecer la suciedad antes de que aflorara, pero ello no era sino impracticable. La Inquisición, por tanto, tenía que acudir frecuentemente a diferentes ritos de purificación que eran los autos de fe.

Veamos, por ejemplo, que el 17 de junio de 1791 fue presentada ante el tribunal del Santo Oficio Agustina Josefa Vera Villavicencio Palacios, a quien se acusa de que lo siguiente:

sufría conmociones de cuerpo, alteración de los humores, con derramamientos o poluciones. Ella creía que el Demonio obraba en ella el derramamiento [...] de suerte que representándosela con demencia una idea torpe en su imaginación, a que seguía delectación y conmoción de los miembros de la sensualidad, la declarante no resistía, porque estaba tan fija su imaginación en la idea obscena, que le pareció fuerza mantenerla en ella, y esperar que el Demonio, a quien hacía autor de todo esto por orden del Señor, acabase con el efecto del derramamiento o polución. Y como creía que todo esto era solamente obra del Demonio, creyó también que en ello quedaba sin culpa. Sin embargo, de condelectarse su voluntad en la sensible delectación de los miembros, porque aunque clamaba al Señor que la quitara aquella tentación, en el acto mismo sentía su voluntad pegada al deleite [...]. (Citado en Baudot 208)

En medio del desarrollo de la performance inquisitorial, el discurso acusatorio contra Agustina opera un giro interesante. La lascivia y el no activar su voluntad para combatirla son las dos razones fundamentales para llevar a esta mujer ante el tribunal del Santo Oficio. Sin embargo, si bien queda probado que ello era suficiente transgresión de las normas, la lascivia por sí parece haber quedado como abstracción, y una posible justificación por intercesión sobrenatural quizás quedaría demasiado etérea: la falta de Agustina debía ser convertida en un hecho contundente. Hasta el demonio queda liberado de culpas. El fallo de Agustina está en ella misma; en algún punto localizado entre su cuerpo biológico y su libre albedrío -bajo el nombre de "voluntad". El agravante para el caso de Agustina es el disfrute de tal incontinencia sexual que es, por supuesto, un desarreglo moral del sujeto femenino colonial. Los términos lascivia, voluntad y disfrute son vocablos que, en el caso de Agustina, refieren a la descomposición moral, pero los tres vocablos tienen en común un alto grado de volubilidad pues los tres resultan conceptos abstractos; ninguno de ellos tiene una representación visual que apoyara la gravedad de la acusación, así como ninguno de ellos remite instintivamente a ningún estado físico que reafirme la gravedad de la falta de esta mujer. El Santo Oficio necesita dar consistencia a su acusación, y lo logra vinculando lo que era violación de la moral a una descomposición de orden físico pues, como bien apunta Maravall, "el hombre del barroco [...] no tiene suficiente confianza en la fuerza de atracción de la pura esencia intelectual y se esfuerza en revestirla de aquellos elementos sensibles que la graben indeleblemente en la imaginación" (502-3). Por ello es que, en el caso de Agustina, lo que es impúdico es traducido en el desarreglo físico de las conmociones. Lo corrupto del comportamiento de esta mujer es reconvenido según una economía de la suciedad física, que es la que mejor puede ser entendida por la población colonial que observa y escucha estos procesos inquisitoriales. La nauseabunda viscosidad que podían sugerir los derramamientos o poluciones de que se vale la acusación es el arma perfecta para articular la falta moral y transmitirla a las diferentes capas de la población observante.

Otro caso interesante es el de Francisca Texoso, presentada en auto de fe por judía judaizante, quien según el mismo inquisidor- "para tener mejor venta el pan que amasaba y que saliese más sabroso y blanco, ella y sus hermanas le amasaban con agua que antes les había servido de lavarse ciertas partes inmundas, haciendo algunos círculos y ritos judaicos en forma de bendiciones sobre la masa" (Documentos 51). El discurso acusatorio, que comienza por una práctica religiosa, salta directamente a una conexión con el cuerpo biológico para luego regresar a lo religioso. En este recorrido, la acusación a Francisca se convierte en una referencia gráfica que despertaría la repugnancia de los asistentes al auto de fe. Solamente después de pasar por el cuerpo, el discurso del acusador regresa a lo ideológico. A nivel simbólico esta mujer está desacralizando uno de los elementos 
esenciales del rito católico: el pan, que se convierte en el cuerpo de Cristo, y que ahora ha sido mancillado por las aguas después de haber completado un recorrido probablemente vagino-anal. Ideología y fisiología vienen a convivir de manera relevante en la acusación. La suciedad que contamina el cuerpo simbólico de Cristo, también incide en el cuerpo social a través de afectar la corporeidad biológica de muchos otros sujetos coloniales. Esta relación ideología religiosa-cuerpo presenta un alto nivel de eficacia: el ejercicio de persuasión que quiere demostrar la peligrosidad de esta mujer solidifica su argumento. Es decir que la posibilidad de polución de esta mujer judía no se queda simplemente en la (quizás dudosa) peligrosidad a niveles ideológicos sino en la contaminación física por la posible ingestión de la suciedad de su cuerpo por otros que consumirían el pan.

Según Solange Alberro, "aunque la lectura de los edictos y la celebración de los autos de fe fuesen tan frecuentes en el virreinato como en cualquier provincia española, éstos carecían de sentido para la mayor parte de la población y su impacto se perdía en un territorio inmenso y discontinuo, en los abismos de la multiplicidad cultural" (79-80). Una muestra singular de la ineficacia del castigo ejemplarizante enarbolado por el Santo Oficio lo tenemos en el caso del sacerdote Francisco de Laxe, residente de la Nueva España, a quien el Santo Oficio encontró una carta dirigida a su amada en la que dice lo siguiente:

Ayer no te escribí porque me fui a Santa Isabel. Me divertí grandemente hasta después de las 8 . Me coronaron de [dronjo ¿?] con la corona de la recién profesa Sor Josefa de los Dolores Fuentes. Hubo fandangos, seguidillas y todo lo demás adherente, hasta las reverendas bailaron el Pan de jarabe. Esto fue por última vez. La madre abadesa estaba apuradita porque el reverendo le negó la licencia para esta función. (Citado por Baudot 47) ${ }^{2}$

Este fragmento en que las infracciones se entretejen no resulta tan largo como enjundioso: como muy evidente tenemos a un miembro del clero que desconoce las regulaciones a las que se encuentra sometido y mancilla el cuerpo eclesial porque (en su cuerpo biológico) mantiene relaciones amorosas con una mujer y practica el "Pan de jarabe", que eran unas coplas acompañadas de un baile específico, perseguidos ambos por la Inquisición mexicana que los consideraba obscenos. Las coplas de estas tonadas se hicieron muy populares en la segunda mitad del siglo XVIII. Estas coplas, entre otras cosas, decían: "Cuando estés en los infiernos, / ardiendo como tú sabes, / allá te dirán los diablos: / 'bay hombre no te la acabes" (Baudot 48). En la letra de esta tonada es evidente la desacralización del relato infernal que integraba la doctrina cristiana haciéndolo coincidir con la referencia a la masturbación que sugiere la forma verbal "acabársela". Como añadidura, tenemos que esto no era únicamente un entretenimiento de la masa poblacional inconexa con los poderes, sino de un sacerdote que participa en las sesiones de canto y baile de lo que la misma Iglesia perseguía como pecaminoso. En tercer término la sesión opera abiertamente ni más ni menos que en un recinto conventual con la participación de las monjas, incluyendo la abadesa. Al traer el pecado a la virtud, el sexo a la castidad y la calle al convento, este sacerdote conjuntamente con las religiosas implicadas, están trayendo la suciedad sobre la limpieza, están creando la polución donde se suponía una cualidad inmaculada de la institución católica. Y todo ello ocurre teniendo al cuerpo como depositario esencial de la suciedad: desde el comer en exceso hasta la relación sexual ilícita; desde el contoneo hasta la masturbación, la Inquisición usa el cuerpo como instrumento esclarecedor de las violaciones religiosas. En la sociedad virreinal la noción de la suciedad viene a funcionar allí donde la hagiografía pierde su efecto.

A decir de Michel Foucault, "los dispositivos del poder se articulan sobre el cuerpo", y es que si la culpa pasa forzosamente por el cuerpo, también los eventos del castigo tendrán en el cuerpo el soporte material imprescindible (Historia 184). Las exhibiciones del castigo que sucedían a los autos de fe eran la etapa final del proceso de purga social; el sambenito localizaba el elemento contaminante y convertía al cuerpo en vehículo visual de la expiación de la culpa, mientras que los azotes sobre el cuerpo purificaban al sujeto y limpiaban la sociedad colonial. En los casos de mayor gravedad, con el cuerpo en la hoguera, la representación de la transgresión se hace etérea, la masa desaparece y con ella la solidez de la suciedad se gasifica. La quema del 
cuerpo es esencial a la institución religiosa porque marca el triunfo del Santo Oficio en la batalla por la eliminación de la suciedad y con ello la disminución de la posibilidad de la polución. El condenado en la hoguera es un ritual de ablución, no poética como la de Balbuena sino física, pero, como ritual que es, su acción se ve limitada al plano de lo simbólico, y en ello sí iguala al ejercicio poético de Balbuena. Es un rito periódico de la ciudad virreinal donde el cuerpo es convertido en espacio de batalla; suciedad y limpieza coloniales libran sobre el cuerpo una lucha por su posesión. Lo físico es una expresión de lo moral, es decir que el cuerpo es tomado por el sujeto; una relación que impone el poder y que no pasará inadvertida por los sujetos coloniales de la capital virreinal, quienes aprenden de las lecciones observadas y usarán su mismo cuerpo como escudo defensor ante el poder. Dentro de la amalgama virreinal el cuerpo se destaca como la mejor y más útil de las posesiones, usado para salir del radio de acción del mismo aparato inquisitorial. En esta tesitura tenemos a Esperanza Rodríguez, acusada y encarcelada por la rama mexicana de la Inquisición en 1646, quien "viéndose apretada, se fingió loca, dejándose comer de piojos; diciendo y haciendo acciones y palabras con que pretendía ser tenida por tal, como eran el coger sus camisas y rasgarlas, haciendo un muñecón grande [...] y besándole hacía que le daba de mamar, diciendo que era su niño" (Documentos 47-8). Esta mujer, conociendo la eficacia del cuerpo físico como divisa comunicativa, decide dos performances - la demencia y la maternidad- practicadas al unísono sobre la materialidad de su propia biología. Esta mujer ha aprehendido que hay desarreglos psiquiátricos que solamente pueden ser representados a través de la suciedad. El no temer al contacto con lo contaminante material condona en ella todo posible contacto con contaminantes ideológicos. Esperanza convierte el cuerpo en un frente defensivo contra el poder y se desmarca, por medio de la suciedad, del radio de acción de la Inquisición.

\section{Palabras finales}

La suciedad no es polvo, ni mancha ni cualquier otra materia o cosa que ensucie, como dice el Diccionario de la Real Academia de la Lengua Española. Tampoco es inmundicia, porquería, ni un dicho o hecho que es sucio, según las acepciones segunda y tercera, respectivamente, del mismo diccionario (www.rae.es). "La suciedad no es una cualidad en sí, sino que se aplica a aquello que se relaciona con un límite y representa, más específicamente, al objeto caído de ese límite” (Kristeva 93). Los poderes coloniales de la ciudad de México, durante los siglos XVII y XVIII, elaboran un orden y todo lo que caiga fuera es excluido en términos del peligro que constituyen como suciedad. Los contaminantes dibujados se graban en la conciencia social por su asociación con actitudes, razas, etnias, prácticas religiosas, y todo un sinfín de peculiaridades observables en el medio colonial.

En la capital novohispana la suciedad es una construcción artificiosa y su característica más importante es su maleabilidad. Los textos analizados en este trabajo son muy diferentes entre sí; todos ellos nacen en condicionantes muy específicos y cada uno de ellos estaba llamado a cumplir objetivos muy particulares. Empero, muy a pesar de las evidentes diferencias entre ellos hay un denominador común y es el establecimiento de ese límite de que habla Kristeva y, sobre todo, la fabricación de una zona oscura de la sociedad virreinal donde se aloja lo patológico. Como bien explica Douglas, "dirt was created by the differentiating activity of mind, it was a by-product of the creation of order [...] its role was to threaten the distinctions made" (198). En La grandeza mexicana y en Alboroto y motín de México, por ejemplo, lo abyecto tiene que ver con grupos de población que quedan alejados del eje de poder y su sistema simbólico. Estos sujetos son convertidos en el parangón de lo abyecto colonial; si bien Sigüenza los nombra con desprecio y los describe literalmente como los alteradores del orden colonial, Balbuena los hace desaparecer. Ellos representan la inmundicia virreinal; la suciedad tiene para ambos autores una significación étnico-clasista.

La pintura de castas se mantiene muy cercana a Balbuena y Sigüenza, pero se interesa fundamentalmente en la etnia y, sobre todo, en el afán de encontrar las áreas de incidencia de la suciedad en variedades de sujetos descalificados porque son portadores de la contaminación de lo malsano colonial que hay 
que controlar antes de que el cuerpo colonial no tenga salvación. Pero en la axiología colonial la preocupación por la contaminación de los territorios coloniales no se circunscribe al aspecto racial; la Inquisición, por ejemplo, determinaba la existencia de la suciedad de manera ideológica. Eran las actitudes de los sujetos las que quedaban bajo la mirada escudriñadora; eran las actitudes, especialmente las referidas a la moral religiosa y que podía llevar al sujeto, según la gravedad de la práctica, a las mazmorras o incluso a la hoguera. Sin embargo, no siempre la suciedad es rechazada. En días de actividades conmemorativas y/o celebratorias, el poder acercaba a la suciedad, la usaba según su propia conveniencia: en estas festividades públicas, indios negros castas, y hasta dementes y homosexuales eran sacados de las sombras, traídos del más allá de las márgenes y exhibidos al centro de las procesiones. El carácter propio de la mojiganga y su inclusión en las celebraciones públicas, aún en las más graves que se relacionaban con santos y reliquias, nos muestra que la suciedad es una construcción antojadiza con la que los sistemas ideológicos o los sujetos particulares elaboran sus discursos.

Es importante tener en cuenta, como última reflexión, que "un sistema simbólico (social) corresponde a una estructuración específica del sujeto hablante en el orden simbólico" (Kristeva 91); es precisamente en ese encuentro entre el sistema simbólico y el discurso que se fragua la suciedad. En los discursos coloniales mexicanos que hemos analizado, la suciedad como tal no existe; ella no es ni física ni etérea. La suciedad es un ardid del discurso, una noción que es elaborada en forma de atributo acucioso para provocar una asociación con lo bajo, lo inmundo, lo desdeñable. La suciedad es usada en los textos analizados para ordenar y controlar a los sujetos coloniales así como para caracterizar y limitar los espacios virreinales. La suciedad como noción es una herramienta eficaz en la construcción de las fronteras ideológicas del mundo colonial. Estos discursos, auto-reconociendo la limitación de no convencer por sí mismos, frecuentemente establecen una relación entre características de una otredad contaminante con el mundo físico. En este maridaje de lo ideológico con lo tridimensional el cuerpo tiene especial importancia porque ofrece una lógica antropomórfica que facilita la materialización por asociación del enunciado ideológico como una verdad. Es con el uso metafórico del cuerpo como apoyatura que la suciedad se hace material, visible, creíble; es a través del uso del cuerpo como metáfora de la producción de suciedad que los discursos coloniales apuestan a ser verosímiles, racionales y aceptados.

Obras citadas

Abarca, P. Mariano de. El sol en león. Solemnes aplausos con que el Rey, Nuestro Señor Fernando VI, sol de las Españas, fue celebrado. México, D.F.: Imprenta de Doña María de Ribera, 1747. Impreso.

Alberro, Solange. Inquisición y sociedad en México. 1571-1700. México, D.F.: Fondo de Cultura Económica, 1988. Impreso.

---. "Modernidad jesuita: la fiestas de las reliquias en la ciudad de México, 1578”. De palabras, imágenes y símbolos. Homenaje a José Pascual Buxó. Coord. y eds. Enrique Ballón Aguirre y Óscar Rivera Rodas. México, D.F.: Universidad Nacional Autónoma de México, 2002. 71-90. Impreso.

Archivo General de la Nación. Universidad Nacional Autónoma de México. Libro primero de votos de la Inquisición de México. 1573-1600. México, D.F.: Imprenta Universitaria, 1949. Impreso.

Arlegui, R. P. Joseph. El moyses de la monarchia de España. Oración fúnebre que en las honras, que hižo la nobilissima ciudad de San Luis de Potosí, a Nuestro Rey, y Señor Don Phelipe V. México, D.F.: Imprenta del Superior Gobierno, y del Nuevo Rezado, de Doña María de Rivera, 1747. Impreso.

Balbuena, Bernardo de. La grandeza mexicana y compendio apologético en alabanza de la poesía. México, D.F.: Editorial Porrúa, 1997. Impreso.

---. Poesía lírica. Ed. Matías Barchino. Ciudad Real: Biblioteca de autores manchegos, 1984. Impreso. 
Baudot, Georges y María Águeda Méndez. Amores probibidos. La palabra condenada en el México de los virreyes. Antología de coplas y versos censurados por la Inquisición en México. México, D.F. y Madrid: Siglo XXI Editores, 1997. Impreso.

Benítez, José R. Historia gráfica de la Nueva España. México, D.F.: Cámara Oficial Española de Comercio de los Estados Unidos Mexicanos, 1929. Impreso.

Bennett, Herman L. Africans in Colonial Mexico: Absolutism, Christianity, and Afro-Creole Consciousness, 1570-1640. Indianápolis: Indiana UP, 2003. Impreso.

Beverley, John. Una modernidad obsoleta: Estudios sobre el barroco. Los Teques, Estado Miranda: Fondo Editorial Los Teques, A.L.E.M., 1997. Impreso.

Bhabha, Homi. The Location of Culture. Londres y Nueva York: Routledge, 2002. Impreso.

Bocanegra, P. Mathías de. Jews and the Inquisition of Mexico: The Great Auto de Fe of 1649. Ed y trad. Seymour Liebman. Lawrence, KS: Coronado Press, 1974. Impreso. Traducción de Auto general de la fe celebrado por los señores, el Ilmo. Y Rmo. Señor Don Iuan de Mañozca, Arçobispo de Mexico, del Consejo de Su Magestad, y de la S. General Inquisición, Visitador de su Tribunal en la Nueva-España. Y por los muy Ilustres Señores Inquisidores Doct. D. Francisco de Estrada, y Escobedo, Doct. D. Inan Saenz de Mañozca, Licenciado D. Bernabé de la Higuera, y Amarilla, y el Señor Fiscal Doct. D. Antonio de Gabrola en la muy noble, y muy leal civdad de Mexico, Metrópoli de los Reynos, y Provincias de la Nueva-España. Dominican Albis 11. de Abril de 1649.

Carrera, Magali M. Imagining Identity in New Spain. Race, Lineage, and the Colonial Body in Portraiture and Casta Painting. Austin: U of Texas P, 2003. Impreso.

Castro, P. Ioan de. Oración panegirica a la celebridad del centenario, que cumplió en su Fundacion el Religioso Monasterio, y Sacro templo de Señoras Religiosas del Convento de la Encarnación. México, D.F.: Viuda de Francisco Rodríguez Lupercio, 1693. Impreso.

Certeau, Michel de. "Spatial Stories." The Practice of Everyday Life. Trad. Steven Rendall. Berkeley: U of California P, 2002. 115-30. Impreso.

---. "Walking in the City." The Practice of Everyday Life. 91-110. Impreso.

---. The Writing of History. Trad. Tom Conley. Nueva York: Columbia UP, 1988. Impreso.

Cervantes de Salazar, Francisco. Crónica de la Nueva España. Madrid: The Hispanic Society of America, 1914. Impreso.

---. México en 1554. México, D.F.: Ediciones de la Universidad Nacional Autónoma, 1939. Impreso.

Cope, R. Douglas. The Limits of Racial Domination: Plebeian Society in Mexico City, 1660-1720. Madison: U of Wisconsin P, 1994. Impreso.

Curcio-Nagy, Linda A. The Great Festivals of Colonial Mexico City. Albuquerque: U of New Mexico P, 2004. Impreso.

Deleuze, Gilles. The Fold: Leibniz and the Baroque. Trad. Tom Conley. Minneapolis: U of Minnesota P, 1993. Impreso.

Documentos inéditos o muy raros para la historia de México. Autos de fe de la Inquisición en México con extractos de sus causas. 1646-1648. Vol. XXVIII. Ed. Genaro García. México, D.F.: Librería de la viuda de Ch. Bouret, 1910. Impreso.

Domínguez Mora, Ramón. "Las inundaciones en la Ciudad de México. Problemática y alternativas de solución." Revista de la UNAM 1.2 (2000): s/p. Web.

Douglas, Mary. Purity and Danger: An Analysis of Concept of Pollution and Taboo. Londres y Nueva York: Routledge, 2002. Impreso. 
Festivo aparato con que la provincia mexicana de Compañia de Jesús celebró en esta Imperial Corte de la América Septentrional, los immarcescibles lauros, y glorias inmortales de S. Francisco de Borja. México, D.F.: Imprenta de Ivan Rvyz, 1672. Impreso.

Foucault, Michel. Aesthetics, Method, and Epistemology. Ed. James D. Faubion. Trad. Robert Hurley et al. Nueva York: The New York Press, 1998. Impreso.

---. Discipline and Punish: The Birth of the Prison. Trad. Alan Sheridan. 2a edición. Nueva York: Vintage Books / Random House, 1995. Impreso.

---. Historia de la sexualidad. Trad. Ulises Guiñ azú. 28ª edición. México, D.F.: Siglo XXI Editores, 2000. Impreso.

---. Power. Ed. James D. Faubion. Trad. Robert Hurley et al. Nueva York: The New York Press, 2000. Impreso.

García, Hugo. "Los elementos visuales en La grandeza mexicana, de Bernardo de Balbuena." Selected Proceedings of the Pennsylvania Foreign Language Conference (2003). Ed. Gregorio Martín. New Kensington: Grelin Press, 2004. 55-62. Impreso.

García Sáiz, María Concepción. Las castas mexicanas. Un género pictórico Americano. Milán: Olivetti, 1989. Impreso.

González Casanova, Pablo. La literatura perseguida en la crisis de la colonia. México, D.F.: Secretaría de Educación Pública, 1986. Impreso.

Grosz, Elizabeth. "Bodies-Cities." Places Through the Body. Eds. Heidi J. Nast y Steve Pile. Londres y Nueva York: Routledge, 1998. 42-51. Impreso.

Gruzinski, Serge. "The Ashes of Desire: Homosexuality in Mid-Seventeenth-Century New Spain.” Infamous Desire: Male Homosexuality in Colonial Latin America. Ed. Pete Sigal. Chicago y Londres: U of Chicago P, 2003. 197-214. Impreso.

---. "Individualization and Acculturation: Confession Among the Nahuas of Mexico From the Sixteenth to the Eighteenth Century." The Church in Colonial Latin America. Ed. John F. Schwaller. Wilmington, DE: Scholarly Resources, 2000. 103-20. Impreso.

Guijo, Gregorio M. de. Diario. 1648-1664. Ed. Manuel Romero de Terreros. México, D.F.: Editorial Porrúa, 1986. Impreso.

Gunew, Sneja. Framing Marginality. Multicultural Literary Studies. Victoria: Melbourne UP, 1994. Impreso.

Herz, Rachel. That's Disgusting: Unraveling the Mysteries of Repulsion. Nueva York y Londres: W.W. Norton \& Company, 2012. Impreso.

Hoberman, Luisa S. y Susan M. Socolow, eds. Ciudades y Sociedad en Latinoamérica colonial. Buenos Aires: Fondo de Cultura Económica, 1993. Impreso.

Ita y Parra, Bartolomé Phelipe de. El arrebatado de Dios. El Señor Don Phelipe V. Oración fúnebre con que expressó el sentimiento de su muerte la América Septentrional. México, D.F.: Viuda de Joseph Bernardo de Hogal, 1747. Impreso.

Kagan, Richard L. Urban Images of America: 1493-1793. New Haven y Londres: Yale UP, 2000. Impreso.

Katzew, Ilona. Casta Painting: Images of Race in Eighteenth-Century Mexico. New Haven y Londres: Yale UP, 2004. Impreso.

Konetzke, Richard. Colección de documentos para la historia de la formación social de Hispanoamérica. 1493-1810. Madrid: Consejo Superior de Investigaciones Científicas, 1953. Impreso.

Kristeva, Julia. Poderes de la perversión. Trad. Nicolás Rosa y Viviana Ackerman. México, D.F./Buenos Aires/Madrid: Siglo XXI Editores, 1988. Impreso.

Laporte, Dominique. Historia de la mierda. Trad. Nuria Pérez de Lara. Valencia: Pre-Textos, 1989. Impreso. 
Leonard, Irving A. La época barroca en el México colonial. Trad. Agustín Escurdia. $4^{\mathrm{a}}$ edición. México, D.F.: Fondo de Cultura Económica, 1990. Impreso.

Maravall, José Antonio. La cultura del barroco. 9a edición. Barcelona: Editorial Ariel, 2002. Impreso.

Mínguez, Víctor. "La fiesta política virreinal: propaganda y aculturación en el México del siglo XVII." La formación de la cultura virreinal. Vol. II. Eds. Kart Kohut y Sonia V. Rose. Frankfurt/Madrid: Vervuert/Iberoamericana, 2004. 359-74. Impreso.

Morales, Pedro de. Carta del Padre Pedro de Morales de la Compañia de Iesús. Para el muy reverendo padre Everardo Mercuriano, general de la misma compañia. En que se da relación de la festividad que en esta insigne ciudad de México se bizo este año de setenta y ocho, en la collocación de las sanctas reliquias que nuestro muy santo padre Gregorio XIII les embió. Ed. Beatriz Mariscal Hay. México, D.F.: El Colegio de México, 2000. Impreso.

Moraña, Mabel. “El 'tumulto de indios' de 1692 en los pliegues de la fiesta barroca. Historiografía, subversión popular y agencia criolla en el México colonial." Agencias criollas. La ambigüedad "colonial" en las letras hispanoamericanas. Ed. José Antonio Mazotti. Pittsburgh: Instituto Internacional de Literatura Iberoamericana/University of Pittsburgh, 2000. 161-75. Impreso.

Pascual Buxó, José. Bernardo de Balbuena. El arte como artificio. Veracruz: Instituto Veracruzano de Cultura, 1998. Impreso.

Pérez de Villagrá, Gaspar. Historia de la Nueva México, 1610. Trad. y ed. Miguel Encinias, Alfred Rodríguez y Joseph P. Sánchez. Albuquerque: U of New Mexico P, 1992. Impreso.

Picón Salas, Mariano. "El barroco de Indias.” Ensayos escogidos. Santiago de Chile: Zig-Zag, 1958. 81-98. Impreso.

Pile, Steve. "Introduction: Opposition, Political Identities, and Spaces of Resistance." Geographies of Resistance. Eds. Steve Pile y Michael Keith. Londres y Nueva York: Routledge, 1997. 1-32. Impreso.

---. y Nigel Thrift. "Introduction." Mapping the Subject: Geographies of Cultural Transformation. Eds. Steve Pile y Nigel Thrift. Londres y Nueva York: Routledge, 1995. 1-12. Impreso.

---. y Nigel Thrift. "Mapping the Subject." Mapping the Subject: Geographies of Cultural Transformation. 13-51. Impreso.

Rama, Ángel. La ciudad letrada. Hanover, NH: Ediciones del Norte, 2002. Impreso.

Ramírez de Vargas, Alonso. Zodiaco illvstre de blasones heroycos, gyrado del sol politico, imagen de principes que ocvltó en su Hercules Thebano la sabiduría mitológica. Deziphrado en poeticas ideas, y expresado en colores de la pintura que en el festivo aparato de el triumphal arco en el mas fausto dia dispuso, y erigió al Exmo Señor Don Joseph Sarmiento Valladares Cavallero del Orden de Santiago, Conde de Monctesuma, y de Tula, Vizconde de Ilucan Señor de la Villa de Monterrosano, y de la Pesa, del Consejo de Su Majestad, Virrey Governador, Capitán General de esta NuevaEspaña, Presidente de la Real Audiencia, y Chancillería, que en ella reside la Santa Iglesia Metropolitana de Mexico. México, D.F.: Imprenta de Joseph Guillena Carrascoso, 1696. Impreso.

Relación del tumulto del dia 15 de Henero de el año de 1624 que sucedió en esta ciudad de Mexico con el Exmo. Señor Marqués de Jelves Virrey Q' fue de esta Nueva España, y Vicita que bizo el Licdo. Don Martín Carrillo y Alderete Visitador General.

Reyes, Alfonso. Letras de la Nueva España. México, D.F./Buenos Aires: Fondo de Cultura Económica, 1948. Impreso.

Rojas Garcidueñas, José. Bernardo de Balbuena. La vida y la obra. México, D.F.: Universidad Nacional Autónoma de México, 1953. Impreso.

Rojas-Mix, Miguel A. La plaza mayor. El urbanismo, instrumento de dominio colonial. Barcelona: Muchnik Editores, 1978. Impreso. 
Romero, José Luis. Latinoamérica: las ciudades y las ideas. México, D.F.: Siglo XXI Editores, 1976. Impreso.

Rubial García, Antonio. Historia de la vida cotidiana en México. Tomo II. La ciudad barroca. México, D.F.: El Colegio de México \& Fondo de Cultura Económica, 2005. Impreso.

---. La plaza, el palacio y el convento. La ciudad de México en el siglo XVII. México, D.F.: Consejo Nacional para la Cultura y las Artes, 1998. Impreso.

Sabat-Rivers, Georgina. "El barroco de la contraconquista: primicias de conciencia criolla en Balbuena y Rodríguez Camargo." Relecturas del Barroco de Indias. Ed. Mabel Moraña. Hanover, NH: Ediciones del Norte, 1994. 59-96. Impreso.

Salazar, Eugenio de. "Epístola al insigne Hernando de Herrera en que se refiere el estado de la ilustre Ciudad de México" / "Descripción de la laguna de México." Poetas novohispanos. Primer siglo (1521-1621). Eds. Alfonso Méndez Plancarte. México, D.F.: UNAM, 1991. 66-76. Impreso.

Sigal, Pete, ed. Infamous Desire: Male Homosexuality in Colonial Latin America. Chicago y Londres: U of Chicago P, 2003. Impreso.

Sigüenza y Góngora, Carlos de. Alboroto y motín de México del 8 de junio de 1692. Ed. Irving A. Leonard. México, D.F.: Talleres Gráficos del Museo Nacional de Arqueología, Historia y Etnografía, 1932. Impreso.

Stallybrass, Peter y Allon White. The Politics and Poetics of Transgression. Ithaca: Cornell UP, 1986. Impreso.

Torres, Daniel. “De la utopía poética en Grandeza Mexicana, de Bernardo de Balbuena.” Ésta, de nuestra América pupila: Estudios de poesía colonial. Ed. Georgina Sabat de Rivers. Houston: Society for Renaissance and Baroque Poetry, 1999. 86-93. Impreso.

---. "Del calco aparente: una lectura de la lírica barroca americana." Conquista y contraconquista. La escritura del Nuevo Mundo. (Actas del XXVIII Congreso del Instituto Internacional de Literatura Iberoamericana). Eds. Julio Ortega y José Amor y Vázquez. México D.F. y Providence: El Colegio de México y Brown University, 1994. 355-62. Impreso.

Universidad Nacional Autónoma de México. El arte efimero en el mundo hispánico. México, D.F.: UNAM, 1983. Impreso.

Vaccarino, Giuseppe. La Suciedad. Trad. Sara Gnavi Bombicci Pontelli. Buenos Aires: Editorial Calicanto, 1978. Impreso.

Van Horne, John. Bernardo de Balbuena. Biografía y crítica. Guadalajara: Imprenta Font, 1940. Impreso.

---. Documentos del Archivo de Indias referentes a Bernardo de Balbuena. Madrid: Tipografía de archivos, 1930. Impreso.

Notas

${ }^{1}$ Según una cronología que presenta John Van Horne, Bernardo de Balbuena fue capellán de la Audiencia de Guadalajara aproximadamente entre 1586 y 1592, luego pasó a ser sacerdote de San Pedro de Lagunillas, aproximadamente entre 1592 y 1606. En este último período estuvo ausente en varias oportunidades: alrededor de 1595 se encontraba en Guadalajara, en 1602 estaba en Culiacán y entre 1602 y 1606 estaba en la ciudad de México (Van Horne, Bernardo 117).

${ }^{2}$ Hasta el momento no sabemos la fecha específica de la carta, pero podemos imaginar que fue escrita en la década de 1770, pues la primera noticia que tenemos de la aparición de las tonadas y el baile llamados Pan de jarabe se remonta a 1772, cuando un religioso de la arquidiócesis de México llama la atención sobre la aparición del canto y la danza en una obra teatral. Ver Baudot, Georges y María Águeda Méndez. Amores probibidos. La palabra condenada en el México de los virreyes. Antología de coplas y versos censurados por la Inquisición de México. México, D.F.: Siglo XXI Editores, 1997. 46-51. 